\title{
NO SERTÃO DA MINHA TERRA - Memórias e musicalidade nos subúrbios do Rio de Janeiro
}

Denise Barata (UERJ)

\begin{abstract}
Pouca gente, hoje, escreve sobre as coisas do Rio de Janeiro. E os poucos que escrevem, se limitam à história. Mas ultimamente um desses escritores [...] resolveu, como Fernão Paes, 'entrar pelo sertão'. Sim, embora o carioca da Avenida, do posto 4, dos chás e cinemas chics fique espantado, existe, nesta sua maravilhosa terra, um 'sertão', como na Amazônia, em Mato Grosso, em Goiás, em Minas, na Bahia. Embora menos bravio... Sim, senhores, o Rio tem o seu sertâo. E que sertão maravilhoso, a cujas verdes portas se pode bater de automóvel, em escassas horas, por ótimas estradas.
\end{abstract}

(Palma, Ricardo in CORRÊA, 1936, p. 11)

Em abril de 2015, participei do Seminário Interlinhas/Encontro Internacional Sertões, Memórias e Oralidades, em homenagem à professora Jerusa Pires Ferreira. No evento, realizado na UFES e na UNEB, apresentei os resultados de minha pesquisa sobre a música no Rio de Janeiro que teve seu início ainda durante o meu doutoramento, sob a orientaçáo da nossa querida homenageada. Entendia que dessa forma, ao tratar da contribuição da professora Jerusa P. Ferreira em meu trabalho, estaria a homenageando. Mais ainda, era uma forma de demonstrar gratidáo por ter acolhido de forma tâo intensa.

Ao ser convidada para escrever esse artigo, porém, pensei em estabelecer uma aproximação maior com o título do evento. Porém, como falar do sertão se pesquiso a música produzida nos subúrbios do Rio de Janeiro? É que, 
Na verdade, o sertão não é um lugar, mas uma condição atribuída a variados e diferenciados lugares. Trata-se de um símbolo imposto - em certos contextos históricos - a determinadas condiçóes locacionais, que acaba por atuar como um qualificativo local básico no processo de sua valoração. Enfim, o sertão não é uma materialidade da superfície terrestre, mas uma realidade simbólica: uma ideologia geográfica. (MORAES, 2002-2003, p. 13).

E foi com a ajuda de Moraes, que lembrei de um livro, que li há anos atrás, intitulado O Sertão Carioca, escrito em 1936, por Magalhães Correa.

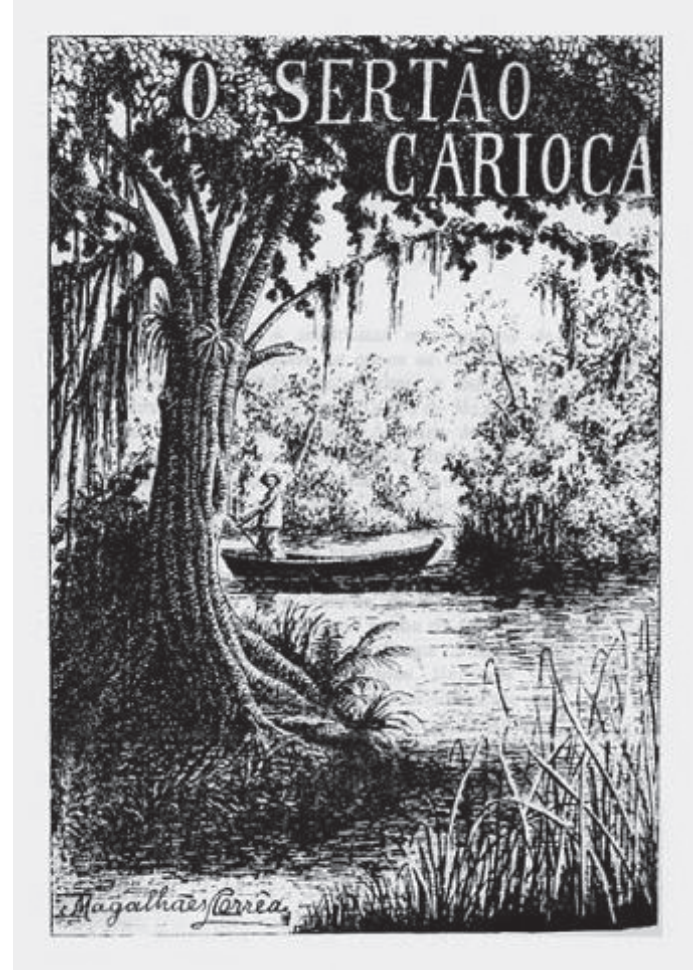

Figura 1. Desenho de Correa.

Fonte: O Sertão Carioca. Folha de rosto.

Nesse livro, o autor delimita uma regiāo da cidade do Rio de Janeiro e a identifica como sertão porém, tanto o texto como os prefácios e comentários, a distinguem de um verdadeiro sertão, mais distante e bravio. 


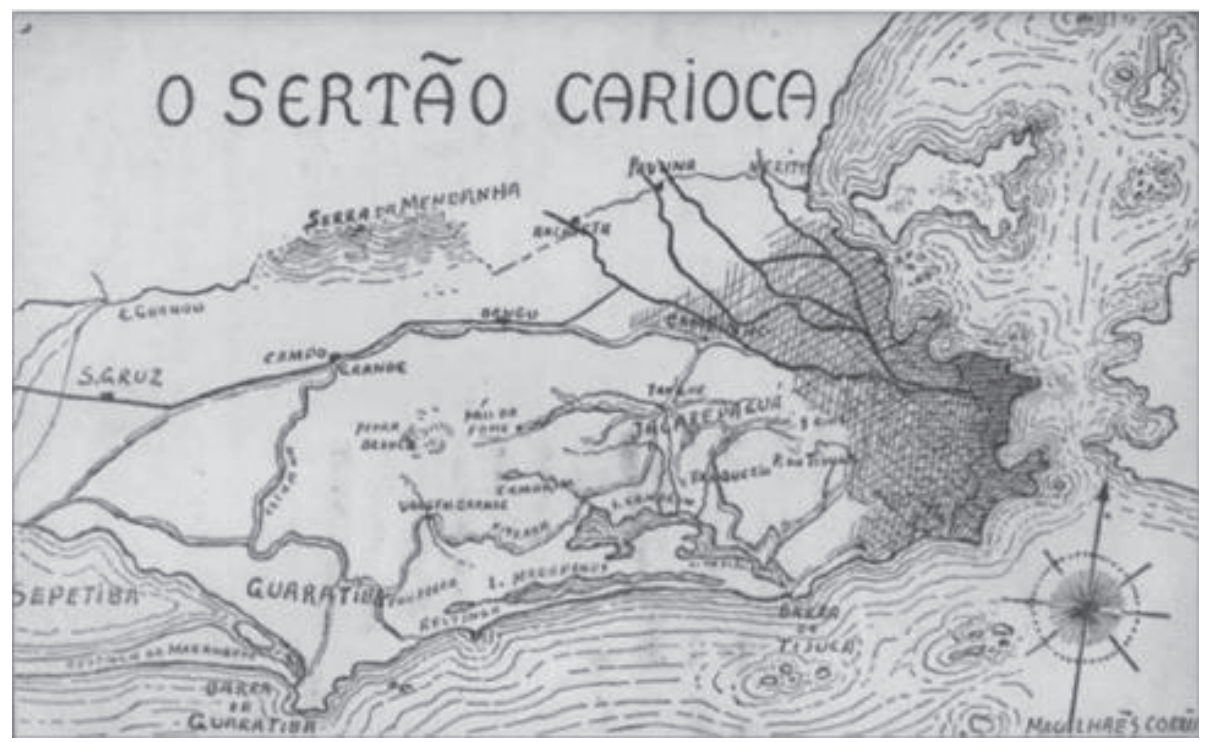

Figura 2. Desenho de Corrêa.

Fonte: O Sertão Carioca, 1936, p.384.

De uma forma geral, quando falamos de sertão estamos nos referindo a lugares distantes e inóspitos, por isso denominar assim uma regiáo da cidade do Rio de Janeiro provoca estranhezas. Além disso, um dos fatos marcantes em relação aos estudos sobre o sertão (e o mundo rural, genericamente falando) é a insistência na demarcação de diferenças. E o que chama atenção no livro de Corrêa é que

O sertão carioca não é visto como ameaça ou resistência ao centro civilizador. O que há de curioso aí é a preservação de formas de vida tidas por autenticamente brasileiras, algumas heranças do período colonial. Em comparação com outros sertôes que se configuram melhor como alteridades exemplares dentro da nação, a região sertaneja do Rio de Janeiro, tal como relatada no livro, gera curiosidade e preocupação quanto à necessidade de evitar sua degradação natural. (SOUZA, 2010, p.7)

Armando Magalhães Correa, autor do livro, nasceu e morreu no Rio de Janeiro (1889-1944). Naturalista autodidata, trabalhou como conservador na Seção de História Natural do Museu Nacional do Rio de Janeiro. Entre suas várias ocupaçóes, trabalhou como escultor, desenhista, professor e escritor.

(...) aprendeu desenhar plantas e animais, habilidade muito valorizada pelos estudiosos da botânica e da zoologia do seu tempo, quando eram limitadas as possibilidades de registro fotográfico de espécimes raros e paisagens agrestes. Os seus conhecimentos de 
história natural e a sua capacidade de produzir imagens sobre a natureza o transformaram em professor do Museu Nacional e da Escola de Belas Artes do Rio de Janeiro. (FRANCO e DRUMMOND, 2005, p. 1037)

Corrêa utilizou seus conhecimentos para registrar, com palavras e desenhos, a paisagem e as conversas realizadas com moradores de uma região que se mostrava invisível para muitos habitantes do centro da cidade. Um dos seus objetivos foi o de apresentar uma região do Rio de Janeiro muito próxima do mundo urbano, localizada a apenas a alguns quilômetros do centro de uma cidade que era a capital da república, a maior do país e a grande representante da cultura litorânea, mas que apresentava problemas típicos do sertão. Seu livro buscou, também, denunciar o abandono da população do "sertão carioca”, com precários níveis de saneamento, educação e assistência médica.

Assim, o autor vai se diferenciar dos que buscavam o Brasil profundo em lugares distantes do interior do país e do mundo urbano. E, em curtas viagens, ele encontrou o "autêntico brasileiro". E é exatamente por isso que ele designa a região como o sertão carioca. (Cf. Souza, 2010)

E em sua preocupação com o sertão, Corrêa se insere em um movimento iniciado com Os Sertóes, de Euclides da Cunha, trinta anos antes, onde este é apresentado como um lugar pobre e agrário que contrasta com o litoral e com os ideais de modernidade que se associam a um Brasil civilizado.

A mudança de título [de A nossa Vendéia para Os Sertóes] não era um simples detalhe. Euclides parecia optar por radical mudança de perspectiva. Diferente dos autores que se dedicaram a analisar a guerra, Euclides tomava outro rumo (...) o relato do conflito configurava um mote para que Euclides refletisse sobre outros temas, principalmente de caráter científico: geologia, botânica, geografia, sociologia, costumes, tradiçốes e folclore. Com a divisão do plano do livro em duas partes, $\mathrm{A}$ natureza e $\mathrm{O}$ homem, ficava mais uma vez estampada a primazia das ciências da natureza no interesse de Euclides. Começava também a aparecer um objetivo mais amplo: o estudo, a partir de bases científicas, dos sertôes. (ABREU, 1998, p.5)

Mas, afinal, onde estava localizado o sertão carioca de Magalhães Corrêa?

A vasta zona da terra carioca, denominada planície de Jacarepaguá (vale dos jacarés), compreendida entre os maciços da Tijuca e da Pedra Branca, é constituída pelos vales dos tributários das lagoas da Tijuca e Camorim; por essas lagoas e a de Marapendy (mar limpo), na restinga de Itapeba (lage), pelos Campos de Sernambetiba e pela Restinga de Jacarepaguá, com suas dunas, a qual é o anteparo do Oceano Atlântico. Começa no Campinho, com o nome de Marangá (vale da batalha) entre este e o morro do Valqueire 
(vale de pau-ferro), na altitude de 40 metros do nível do mar. No Tanque, a 14 quilômetros do Campinho, dilata-se consideravelmente, chegando a ter 6 quilô- metros de largura. Deste ponto, vai progressivamente aumentando, até encontrar o Oceano, onde alcança a sua maior largura, formada pela bacia hidrográfica das lagoas da Tijuca, Camorim, Marapendy e Campo de Sernampetiba. Aí da Barra da Tijuca (morro da Juatinga - Juá branco) até a base do Morro das Piabas, alcança 23 quilômetros de extensão, mais ou menos. Do Campinho ao Oceano, a extensão é de 15 quilômetros; o terreno vai em declive suave, seco, até as Estradas da Tijuca, do Camorim, Vargem Grande e Piabas; (...). (CORRÊA, 1936, p. 23)

Apesar da delimitação apresentada por Corrêa, para Afrânio Peixoto, escritor e médico sanitarista, o sertão carioca estava localizado no final da Avenida Central, na atual Avenida Rio Branco, situada no centro da cidade. Para Peixoto (Apud HOCHMAN, 1998, p. 01), "O nosso sertấo começa para os lados da Avenida."

É importante lembrar que o centro da cidade sofreu uma reforma empreendida por Pereira Passos, prefeito entre 1902 e 1906. Com essa reforma, muitos descendentes dos homens e mulheres que foram escravizados nesse país foram deslocados para o final da Avenida, que também era conhecida como a Pequena África, e para os morros e bairros do subúrbio.

Ainda nos dias de hoje, em pleno século XXI, muitas pessoas continuam a considerar o Rio de Janeiro como composto apenas pela zona central, sul e parte da oeste, onde estáo localizados o centro financeiro e moradias de alto custo. A cidade Rio de Janeiro ainda se apresenta "partida", com territórios bastante delineados, em uma tentativa de impossibilitar o trânsito e diálogo entre eles, interditando-se a livre circulação de bens simbólicos e dos sujeitos. Zona sul, zona norte. Classe dominante, classe dominada. Cultura erudita, cultura popular. Divisão no indivisível. Definidos os lugares de saber, a circulação dos sujeitos em seus espaços sociais é legitimada. Porém, essas relações não são mecânicas. Há confrontos. E a cidade não é apenas um espaço físico, mas também um espaço que nos comunica mensagens, símbolos e significados, onde se confronta uma multiplicidade de culturas. Ela é, também, um signo que comporta vários territórios, várias culturas e saberes, que realiza (ou dificulta) trocas simbólicas de informaçôes. Enfim, na cidade circulam vários modos de ser, em territórios diferenciados de cultura e saberes, comunicando uma forma particular de pensar, sentir e agir no mundo. Precisamos, porém, atentar para as práticas e sujeitos que tentam subverter essa ordem e que resistem, não através dos conflitos, mas no cotidiano, em uma luta para instaurar na memória da cidade os seus valores simbólicos. 
A cidade do Rio de Janeiro foi a cidade do continente americano que mais recebeu africanos para serem escravizados, sendo que seus descendentes, em função das inúmeras reformas implementadas, viveram em uma "diáspora" constante, sendo "empurrados" para a periferia e para os morros. De uma forma geral, quando falamos do Rio de Janeiro, ele está restrito às praias da zona sul, à bossa nova e ao carnaval televisionado. Quando, porém, estudamos a história dessa cidade, ficamos assustados com depoimentos de viajantes ${ }^{2}$ que a ela se referiam, no século XIX, como a África Atlântica. Que Rio de Janeiro eles conheceram?

Recorrendo aos dados fornecidos por Karasch (2000), podemos afirmar que nenhuma cidade da América se aproximou em número de africanos como Rio de Janeiro. A presença física e simbólica negra era constante, principalmente nos espaços públicos: ao caminhar pelas ruas do centro do Rio de Janeiro, com sua mulher e filhos, os prósperos negociantes portugueses e brasileiros eram obrigados a conviver com outros valores. Ocupando os lugares públicos, as práticas simbólicas negras eram encaradas como desafio. Para os desconhecedores das formas de expressão negro-brasileiras todas essas atividades eram apenas festas. Sim, são festas. E essa é a forma que a população negra possui de manter sua memória, se conectando com seus ancestrais, mantendo-os vivos, com muita alegria.

É essa cultura afro-carioca, forjada a partir das muitas tradiçôes culturais da primeira metade do século XIX que continua a dar força cultural ao Rio contemporâneo, onde o samba ainda é dançado, instrumentos da África Central ainda são tocados e espíritos Africanos ainda são reverenciados. (KARASCH, 2000, p.109)

Ainda nos dias de hoje, as festas, os pagodes e as rodas de samba são algumas das formas que as comunidades encontraram de se colocarem no mundo e manterem a memória dos seus grupos. São suas vozes que cantam e seus corpos que dançam na concretização da memória da comunidade, apesar das tentativas de invisibilização que concretizam uma forma de racismo extremamente sutil.

\section{A Grande Madureira}

Distante quase 40 quilômetros do centro da cidade, a região que denomino de Grande Madureira (Marechal Hermes, Bento Ribeiro, Oswaldo Cruz, Madureira e Serrinha) é vizinha da região denominada Sertão Carioca por Magalhães Corrêa ${ }^{3}$. 


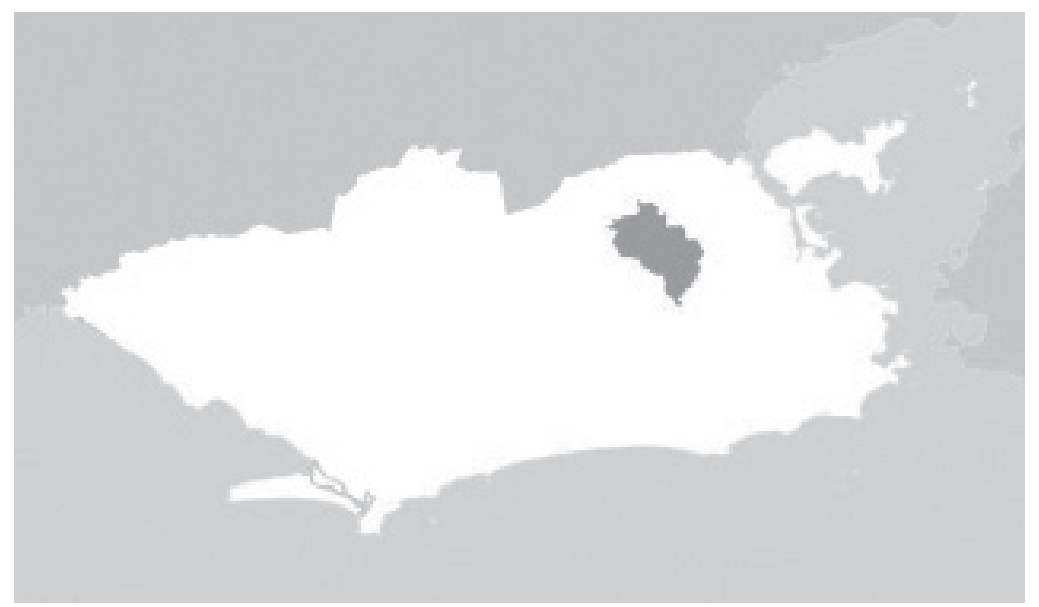

Figura 3. Imagem com a localização da região da Grande Madureira no mapa da cidade do Rio de Janeiro, sendo que a cor azul representa o mar.

Fonte: Instituto Dereira Dassos, Drefeitura da Cidade do Rio de Janeiro

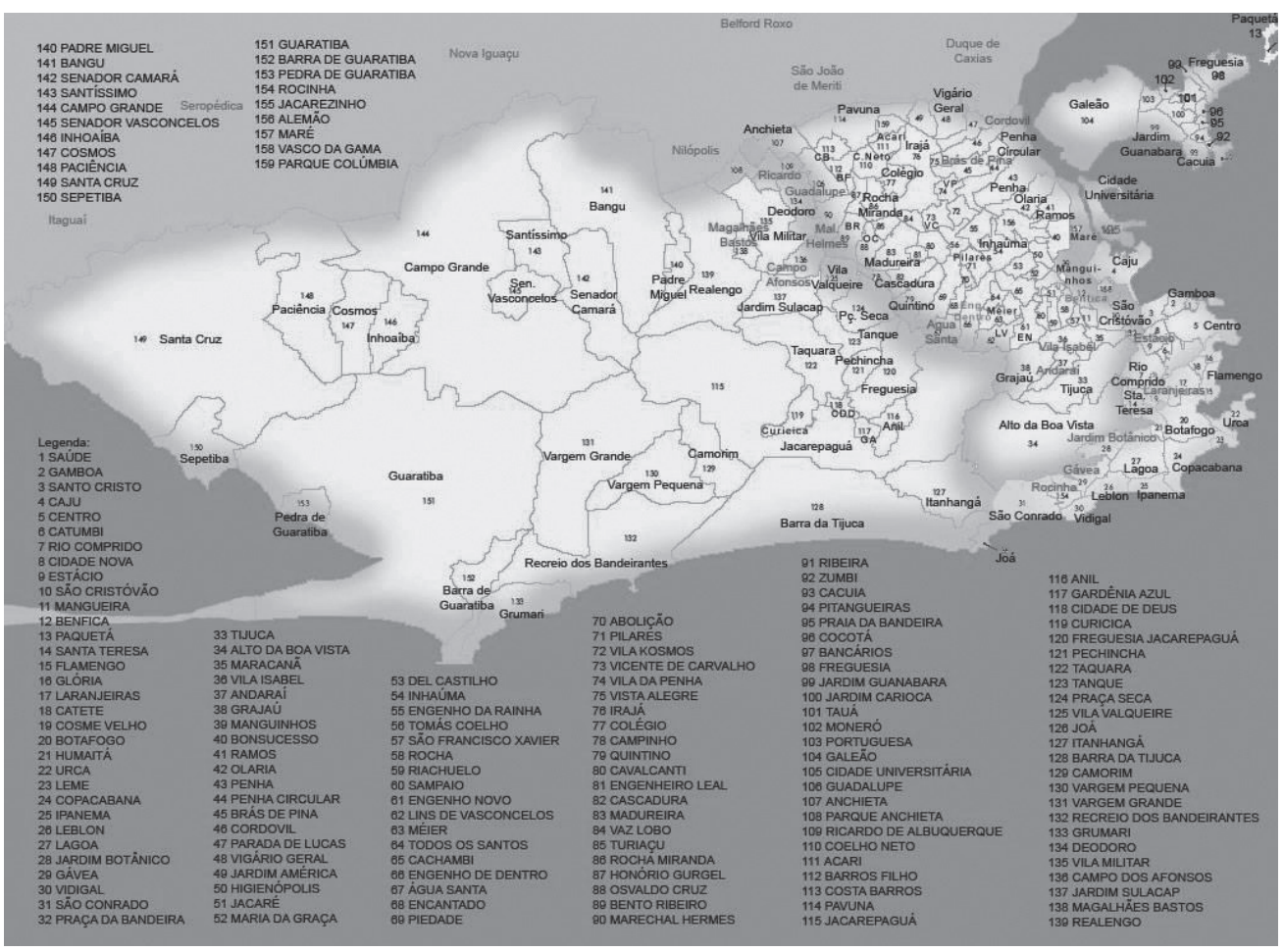

Figura 4. Mapa da Cidade do Rio de Janeiro e seus Bairros. Fonte: Prefeitura da Cidade do Rio de Janeiro 
Essa região abriga um rico patrimônio cultural imaterial, composto de músicas, histórias, comidas e danças que fazem parte da cultura do Brasil. Apesar de frágil, o patrimônio cultural intangível é um fator importante na manutenção da diversidade cultural em um mundo cada vez mais globalizado. Ter uma ideia do patrimônio cultural imaterial das diferentes comunidades é fundamental para a promoção do diálogo intercultural e do respeito pelos outros estilos de vida. Além disso, o patrimônio cultural intangível tem consideraçóes sociais e econômicas e pode vir a se tornar fonte de renda para grupos sociais minoritários.

Assim, a proposta da pesquisa escolheu uma regiáo que construiu e mantém uma intensa produção simbólica, apesar de ser praticamente invisível para os que habitam a zona sul da cidade. Mas o que se percebe lá é o poder de sua cultura em gerar renda informalmente e manter, de uma forma quase invisível para o resto da cidade, as tradiçôes negras do Rio de Janeiro.

É nesta região que estão duas grandes escolas de samba da cidade (GRES Portela e GRES Império Serrano), e onde proliferam vários pagodes e rodas de samba, de choro e de jongo, tudo isso reflexo da enorme produção simbólica na região - uma vocação ancestral. Além disso, considero que um dos principais fatores para a escolha do local foi o vínculo afetivo, já que nasci e fui criada em Bento Ribeiro, local de residência de boa parte de meus familiares. Junto a isso a participação do meu avô paterno na construção da história musical dessa região.

\section{Memória em Ação}

Em um estudo que busca tratar de formas distintas de saberes e fazeres que se constroem a partir de modelos que se distanciam sobremaneira dos modelos universalizantes de cultura, faz-se necessário um olhar problematizador sobre as fontes e sobre a forma de observação em campo. Para tanto, recorri à observação participante, à história oral e a etnohistória.

A relação entre a etnologia e a história vem contribuindo para a utilização do método comparativo histórico, através da utilização de fontes documentais tradicionais, tais como textos escritos primários, assim como uma bibliografia secundária sobre o tema. A valorização potencial de toda sorte de documentos significou um aprofundamento significativo da sensibilidade para com os mais diversos aspectos da experiência humana e a incorporação de diferentes tarefas metodológicas. A partir de um rompimento com concepçôes arraigadas do que é documento, podemos ampliar a nossa relação com outras ciências humanas; e o trabalho de coleta de depoimentos orais utiliza procedimentos que contribuem para a constituição de novas fontes. 


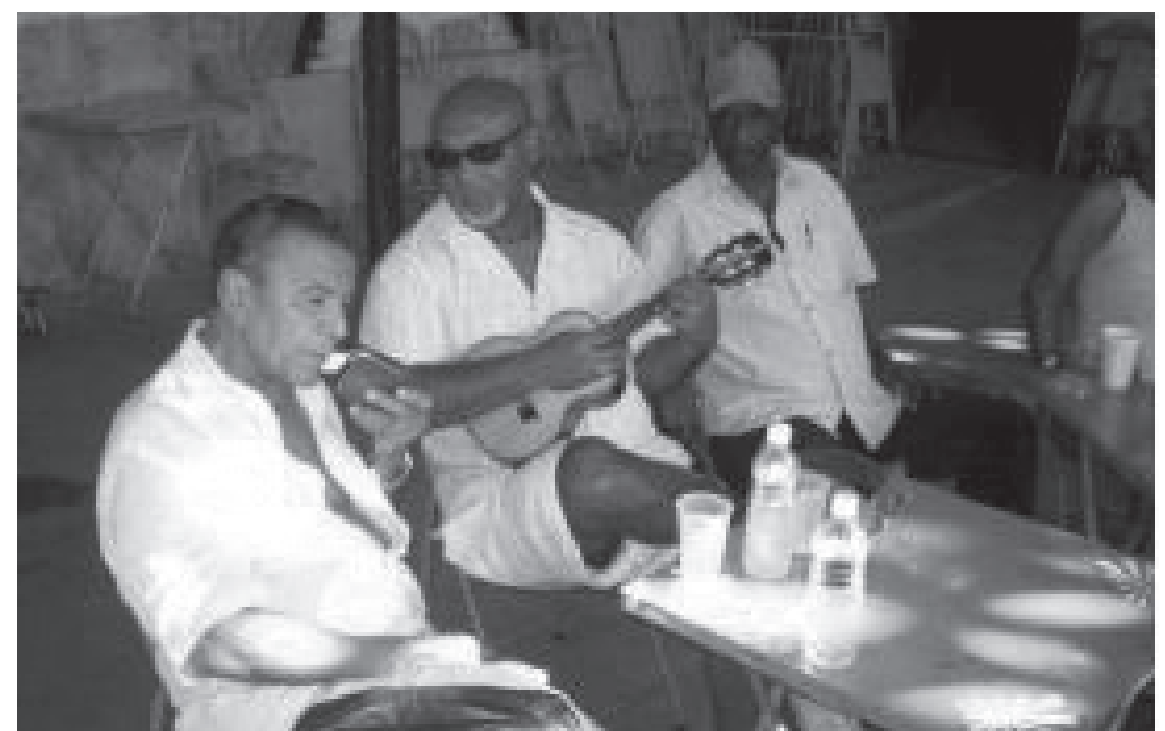

Figura 5. Durante uma entrevista na Sede da Dortelinha, um encontro de três grandes compositores da região: Monarco (Hildimar Diniz), Mauro Diniz e Edir Gomes.

Fonte: Denise Barata

Neste trabalho, ao tratar da memória de indivíduos, não estou me referindo apenas ao que é verbalizado através das palavras. Memória é muito mais do que o que é lembrado. É o que é esquecido. Não apenas o que está na mente, mas o que está guardado no corpo, tal como a forma de andar, falar, dançar etc. O corpo é lugar de memória. Por este motivo utilizei o registro em vídeo.

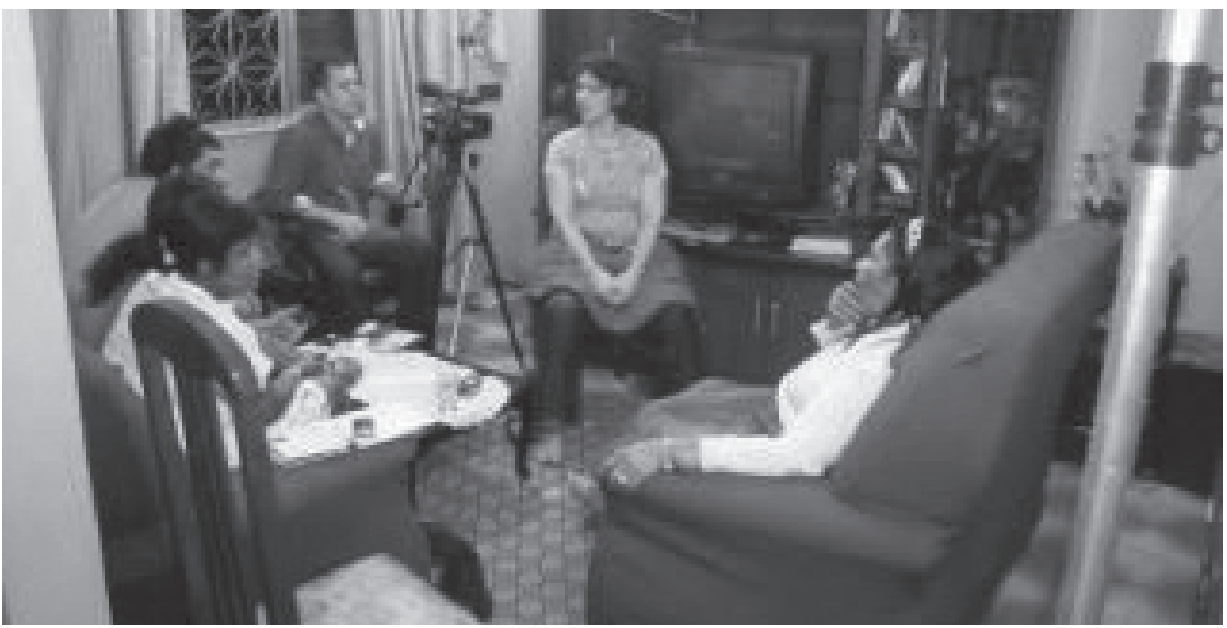

Figura 6. Entrevista com Tia Doca (Jilçária Cruz Costa), membro da Velha Guarda da Dortela, falecida em 21/01/2009. Fonte: Helena Machambisse 
Optar pela história oral, me levou a buscar, como nos diz Pierre Bourdieu, "construir uma narrativa que dê conta dos elementos contraditórios que constituem a identidade de um indivíduo e as diferentes representaçôes que dele se possa ter conforme os pontos de vista e as épocas". Assim, esta metodologia não transforma o pesquisador em um técnico que apenas registra o que é falado, pois essas narrativas não podem substituir a pesquisa e muito menos sua análise. A história oral não deve ser encarada como um trabalho apenas técnico. Realizar entrevistas, fazer perguntas, registrá-las, transcrevê-las, afinal, como nós, pesquisadores-sujeitos, nos colocamos diante do outro "informante" - sujeito? Como nos situamos diante de outras formas de conhecer, pensar e sentir o mundo? Como considerar o distanciamento entre a fala e a percepção que temos dela? Com tantos fatos a considerar, como podemos tratar a informação que temos diante de nós, como algo que pode ser apreendida de forma homogênea, única, fixa e imutável? As histórias de vida ouvidas e entendidas em episódios, em momentos de afloramento de práticas pessoais e sociais estáo sempre ligadas às condiçôes de emissão, a especificidade dramática de situaçôes e interferência de enredos prévios que então se articulam. Estão portanto em causa muitos atos de entendimento, decifraçóes possíveis, empatias e contra-empatias, momentos distintos no curso de um tempo que se desenrola, de modo diferente.

(...) Seria bom, no entanto, lembrar que estamos diante de fenômenos de comunicação que não prescindem de uma avaliação dos processos-transmissivos. A memória aí é pensada enquanto transmissão, organização dramática em que se transmite, inventa e articula. (FERREIRA e AMADO, 1997, p. xxiv)

Sabemos, também, que nem sempre é possível comprovar a veracidade dos fatos relatados, o que não compromete a metodologia. $\mathrm{O}$ que o sujeito afirma ter acontecido, sua interpretação e suas lembranças e esquecimentos constituem sua identidade, dizem respeito aos seus valores sociais e representam um estímulo ao seu comportamento. Importa-nos o que foi escolhido para ser perpetuado em sua memória. Por isso, privilegiei as grandes riquezas da comunicação oral: a energia, a emoção e envolvimento multisensorial, que nos possibilita acesso a conhecimentos "escondidos", que se colocam além da linguagem verbal. Essa metodologia pressupõe que a relação entre o pesquisador e os sujeitos seja construída a partir de interaçôes dialógicas, onde nem sempre, nós, pesquisadores, temos o domínio total do conhecimento que é produzido, já que ela não desconsidera o lado subjetivo da experiência humana.

Nesse sentido, é fundamental o contato no âmbito da pesquisa de campo com a história de vida daqueles que viveram a dinâmica cultural, social e política destes 
lugares, colaborando com um rico material para a construção de fontes para a história oral, trazendo uma documentação alternativa para esse tipo de metodologia. E, para isso, realizei diferentes formas de entrevistas, dependendo da(s) pessoa(s), do momento, do assunto: entrevistas individuais, entrevistas coletivas, conversas informais durante festas, encontros comunitários, ensaios e apresentaçóes musicais ${ }^{4}$.

Busquei com o entrelaçamento entre a palavra, a voz e o corpo criar possibilidades de apreensão da dinâmica da cultura na construção dos espaços, em uma realização performática da existência. Creio que dessa forma, poderemos observar inúmeras culturas que estabeleceram formas eficientes de ser, de entender e de representar o mundo segundo outras dinâmicas (conto, canção, rito, dança) que se diferenciam da palavra escrita, ou como fala apartada da corporeidade, aproximando-se da ideia de performance, que "é o sabe-ser. É um saber que implica e comanda uma presença e uma conduta, um Dasein comportando coordenadas espaço-temporais e fisiopsíquicas concretas, uma ordem de valores encarnada em um corpo vivo." (Zumthor, 1996, p.31). Transcendendo o âmbito da oralidade, a performance pode fornecer uma estratégia heurística aos estudos sobre as diversas maneiras de como essa cultura se manifesta.

\title{
A Geografia da Memória
}

\author{
"As margens da memória, \\ uma vez fixadas com palavras, \\ cancelam-se. \\ Pode ser que eu tenha medo \\ de, repentinamente, perder Veneza, \\ se falar a respeito dela. \\ Ou pode ser que, falando de outras cidades, \\ já a tenha perdido pouco a pouco.”
}

(Calvino)

Para registrar a história da região poderia ter recorrido apenas a arquivos e bibliotecas porém, nessa proposta, optei por trabalhar com as memórias dos moradores da região, relacionando-me com as suas histórias como potência de vida. E não apenas com entrevistas formais, mas oportunizando todo tipo de encontro e experimentando e participando de festas, celebraçóes e reuniōes. Tudo isso têm me possibilitado registrar fatos, lugares, pessoas, sonoridades e conhecimentos e o resultado será a produção de uma cartografia poética-musical coletiva. 
Tradicionalmente, a cartografia traça mapas, buscando representar um território e/ou a distribuição da população em determinado espaço e suas características.

O termo cartografia utiliza especificidades da geografia para criar relaçóes de diferença entre territórios e dar conta de um espaço. Assim, Cartografia é um termo que faz referência à ideia de mapa, contrapondo à topologia quantitativa, que caracteriza o terreno de forma estática e extensa, uma outra de cunho dinâmico, que procura capturar intensidades, ou seja, disponível ao registro do acompanhamento das transformaçóes decorrias no terreno percorrido e à implicação do sujeito percebedor no mundo cartografado. (FONSECA e KIRST, 2003, p.92).

Aqui, porém, cartografia é entendida além do mapeamento físico, já que inclui movimento, lutas e conflitos. Ela é um processo, e não a representação de um objeto.

(...) o mapa é aberto, é conectável em todas as suas dimensóes, desmontável, reversível, suscetível de receber modificações constantemente. Ele pode ser rasgado, revertido, adaptar-se a montagens de qualquer natureza, ser preparado por um indivíduo, um grupo, uma formação social. (DELEUZE, 1995, p.22)

O mapa passa a ser um objeto estético que incorpora valores e que configuram espaços, concentrado na experiência, no percurso e nas suas dinâmicas. E por isso ele nunca estará pronto, será sempre fragmento, em um eterno e infindo movimento de sua produção.

A partir daqui, apresentarei os lugares de memória, os músicos e as práticas simbólicas que mais mereceram destaque nas conversas e entrevistas realizei. 


\section{O bairro de Marechal Hermes:}

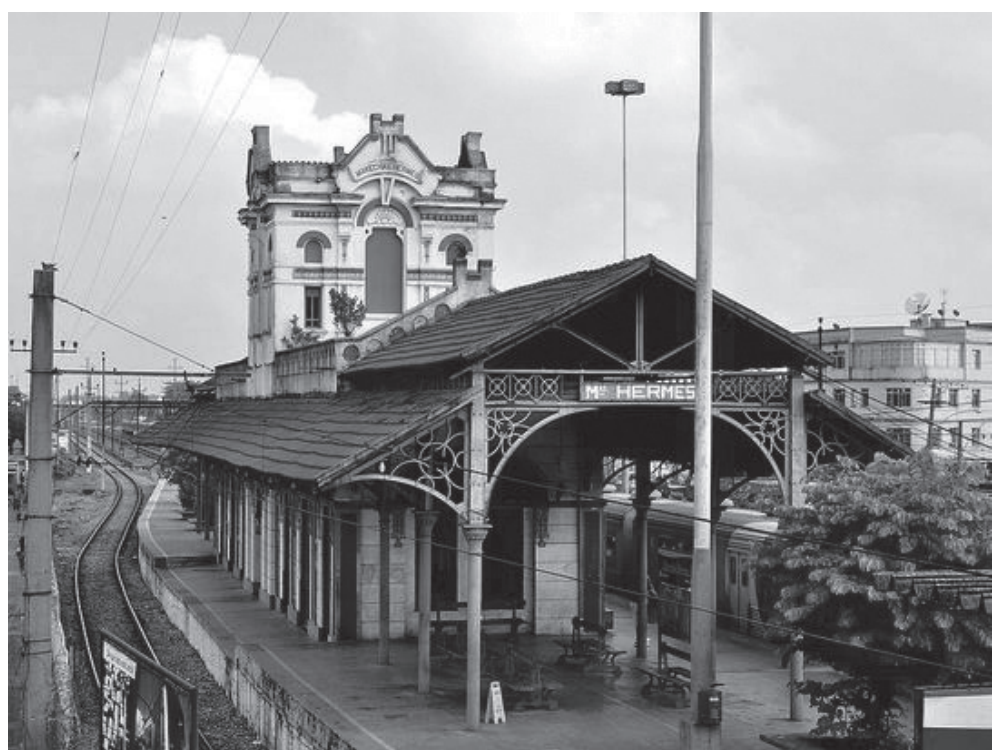

Figura 7: Estação Ferroviária de Marechal Hermes

Fonte: http://www.wikirio.com.br/images/c/c3/56377t5607_e4d085728d_z.jpg

Um dos berços do chorinho no Rio de Janeiro, Marechal Hermes um abriga uma bela estação ferroviária de estilo eclético, construída em 1913. Neste bairro viveram Luperce Miranda (Luperce Bezerra Pessoa de Miranda), que junto com Jacob do Bandolim (Jacob Pick Bittencourt), foi um maiores compositores de choro do país; Lalau (Laudelino Procópio da Silva), grande cavaquinista e banjista do choro; Osmar do Cavaco (Osmar Procópio da Silva), músico de Clara Nunes e Candeia; e Serginho Procópio (Sergio Procópio da Silva), compositor renomado, gravado por Zeca Pagodinho e Dudu Nobre, atualmente membro da Velha Guarda da Portela e presidente do GRES Portela. 


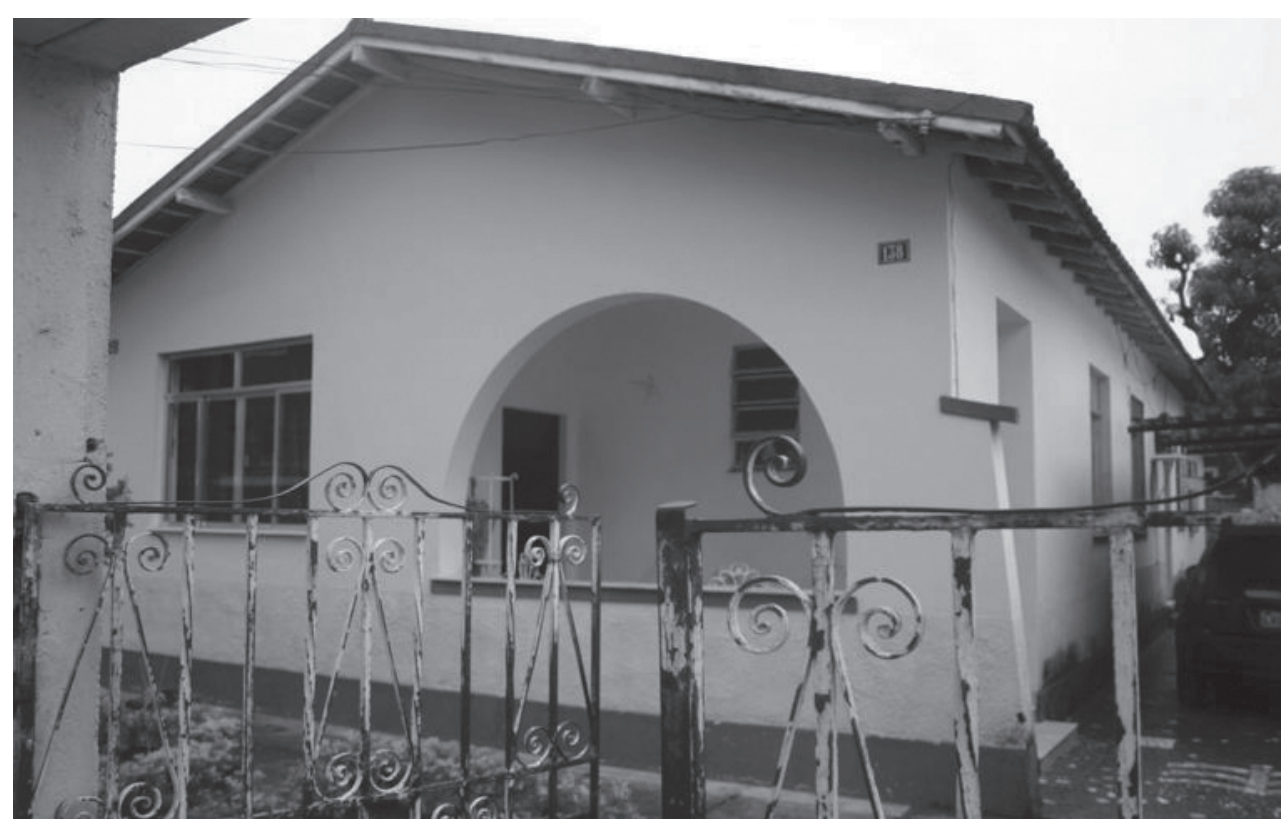

Figura 8: Casa onde viveu o. Osmar do Cavaco, em Marechal Hermes. Fonte: Denise Barata

\section{O bairro de Bento Ribeiro:}

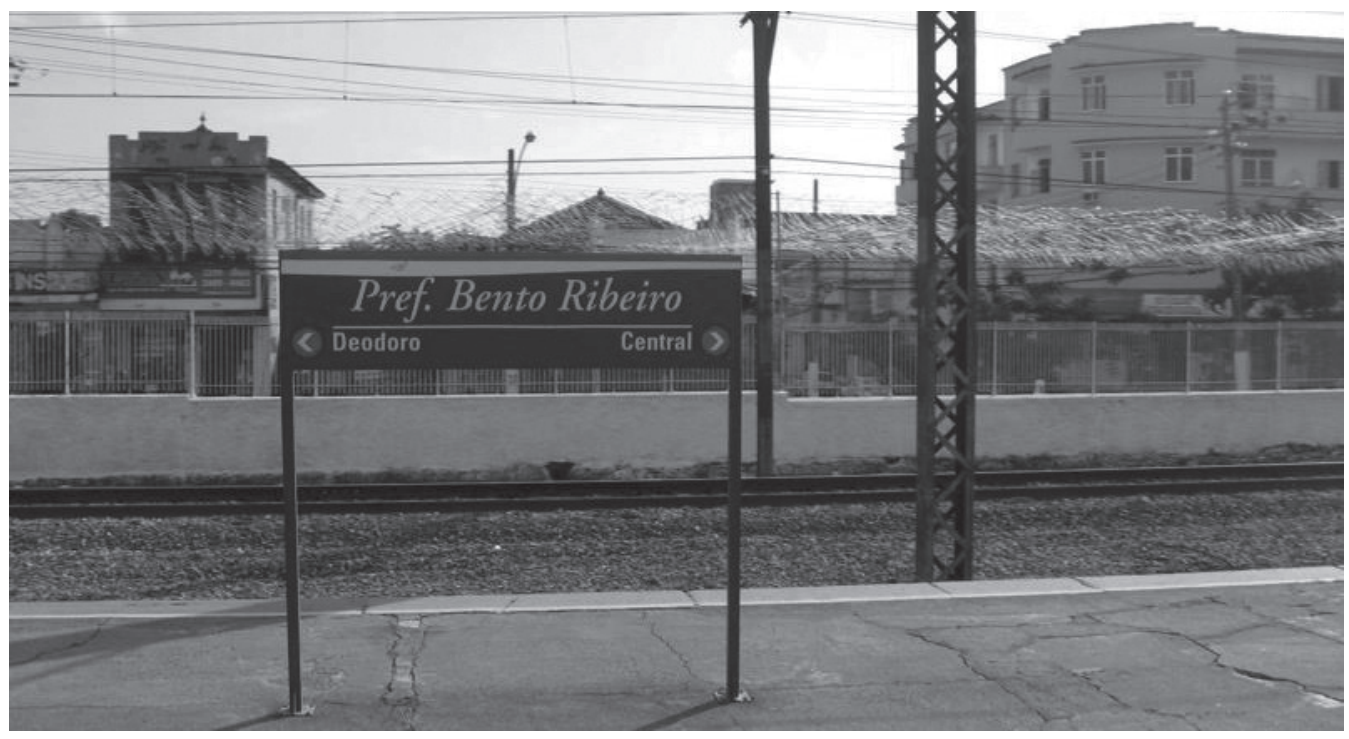

Figura 9: Esstação Ferroviária de Bento Ribeiro

Fonte: https://upload.wikimedia.org/wikipedia/commons/5/5d/Estação_Bento_Ribeiro.JPG 
Durante várias décadas, funcionou nesse bairro a Gafieira Cedofeita, ponto de encontro de diversos músicos, como Paulo da Portela (Paulo Benjamin de Oliveira), Jameláo (José Bispo Clementino dos Santos), Cartola (Agenor de Oliveira), Carlos Cachaça (Carlos Moreira de Castro) e Dominguinhos (José Domingos de Moraes) e espaço de desafios entre o trombonista Naval (Prudêncio Paulo Barata) e Pixinguinha (Alfredo da Rocha Vianna Filho).

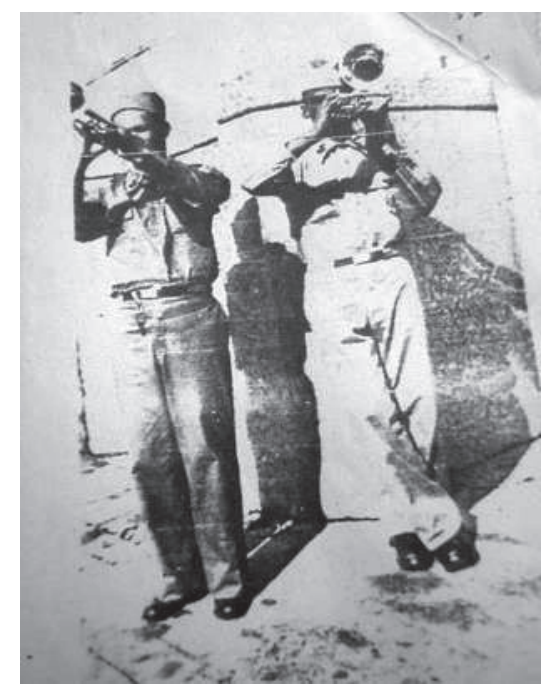

Imagem 11: Naval e de seu irmão José Barata. Fonte: Jornal não identificado

Lá também viveu Zé Ketti (José Flores de Jesus), grande compositor, que teve seus sambas gravados por Maria Bethania, Elis Regina, Nana Caymmi, entre outras. A memória musical desse grande compositor, membro da ala de compositores do Bloco Carnavalesco Lá e Cá, agremiação de Bento Ribeiro, foi gestada na quadra portelense e no samba das gafieiras de Bento Ribeiro, facilmente perceptíveis em sua sonoridade.

Também foram destacadas duas escolas de samba do bairro: a Lira do Amor, que teve Paulo da Portela como um de seus membros, e a Paz e Amor. Outro nome recorrente na história do bairro é o do percussionista e mestre da bateria da Portela Armando Marçal e do compositor Paquito (Francisco da Silva Fárrea Jr), autor de famosos sambas e marchas como Patrão, o trem atrasou, Não me diga adeus, Daqui não saio e Tomara que chova. 


\section{O bairro de Oswaldo Cruz}

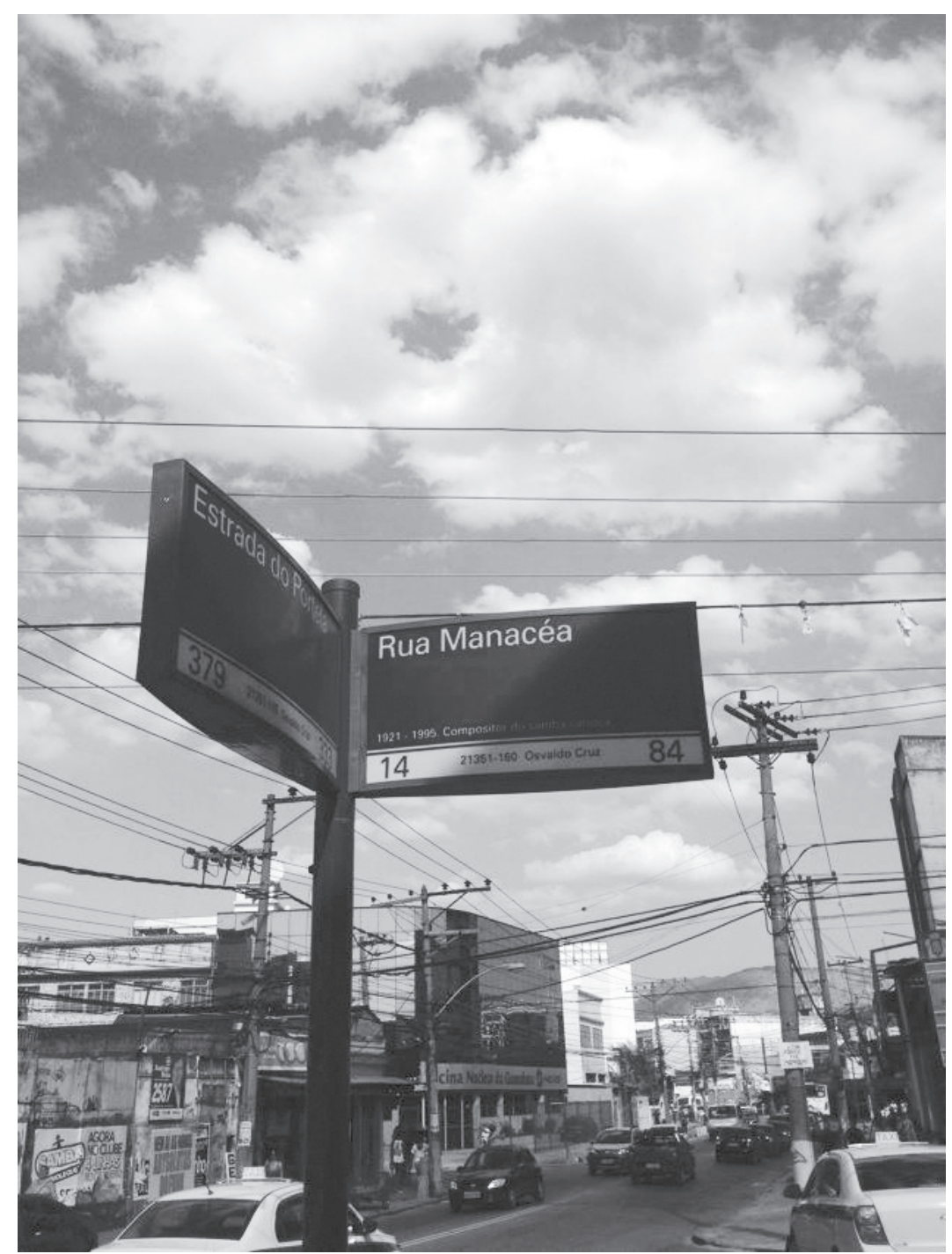

Figura 11. Placa na esquina da rua Manacéa com a Estrada do Portela, em Oswaldo Cruz. Fonte: Denise Barata

Um dos berços do samba e do jongo, as memórias desse bairro dirigem-se à Portelinha, antiga sede da GRES Portela. Lá era possível ouvir as vozes e as poesias de Manacéia (Manacéa José de Andrade), Walter Rosa, Candeia (Antônio Candeia Filho), Alcides Malandro Histórico (Alcides Dias Lopes), Monarco e Zé Kéti, entre outros. 
Essas memórias estão também no Botequim do Nozinho, local que também foi sede da Portela. Com a presença constante de vários compositores da cidade, o botequim se transformou em um ponto de encontro dos sambistas de várias escolas. Destaque do bairro é a casa Paulo da Portela, compositor, dançarino e versador; a casa onde viveu Candeia, compositor de obras primas como "Preciso me encontrar", "Filosofia do Samba" e "Dia de Graça"; e a Barra Preta, local onde morou Paulo da Portela e que foi uma das sedes da escola;

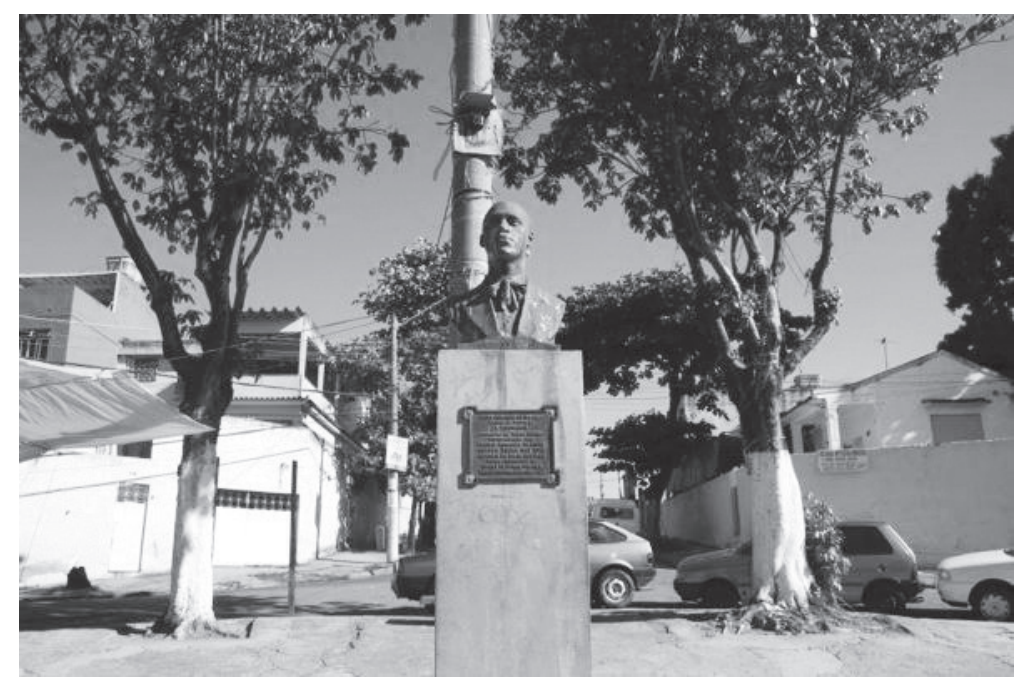

Figura 12. Busto de Daulo da Dortela em praça de mesmo nome, em Oswaldo Cruz. Fonte: Denise Barata

Grande destaque também foi dado ao botequim frequentado pelo compositor portelense Chico Traidor (Francisco Felisberto Santana), autor do hino da escola e de sambas memoráveis como "Um saco de feijão", grande sucesso na voz de Beth Carvalho; e à leiteria que reunia a nata dos compositores da Portela após os ensaios.

As memórias do jongo estão na casa da Vovó Dorotéia, grande jongueira da regiáo, que também era parteira e curandeira e que morreu com mais de 110 anos. Estão também na casa do Seu Napoleão do Nascimento, onde Seu Vieira comandava as rodas de Jongo.

As memórias das religiôes negro brasileiras estão materializadas na casa de Dona Esther Maria Rodrigues, uma das grandes matriarcas do samba. Em sua casa aconteceram festas memoráveis que reuniram músicos como Pixinguinha, Luperce Miranda e Paulo da Portela, sendo ela, por isso, considerada a Tia Ciata do subúrbio. 


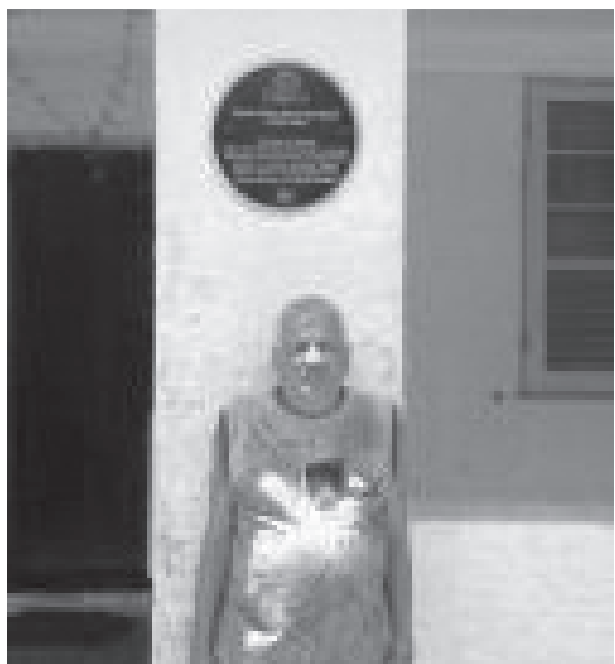

Figura 13. Seu Mirinho (Waldomiro Rodrigues), sobrinho de D. Esther, na frente da varanda de sua casa. Acima podemos ver a placa marcando o lugar.

Fonte: Denise Barata

Essas memórias estão, também, na casa da Dona Neném do Bambuzal, mãe de santo da região, onde aconteciam festas que reuniam personagens do mundo do samba; e na casa da Dona Nira, afilhada de Dona Neném e filha do lendário Jaburu da Portela (Compositor e diretor de harmonia da escola), sendo sua casa uma das poucas remanescentes do inicio do século passado.

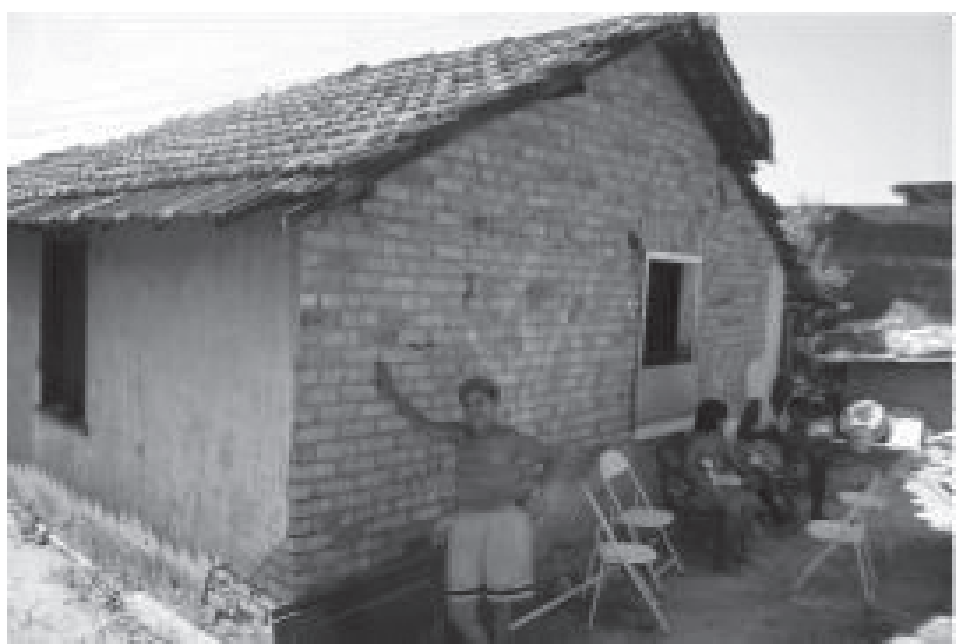

Figura 14. Tia Nira, na frente de sua casa. Fonte: Denise Barata 
Para concluir, vale lembrar que Oswaldo Cruz foi o bairro que abrigou vários compositores famosos, tais como Monarco, Casquinha (Otto Henrique Trepte), Alvaiade (Oswaldo dos Santos), Argemiro do Patrocínio, Jair do Cavaquinho (Jair Araújo da Costa), Jorge Bubu, Mijinha (Bonifácio José de Andrade), Aniceto (Aniceto José de Andrade), entre tantos outros.

\section{O bairro de Madureira e o morro da Serrinha:}

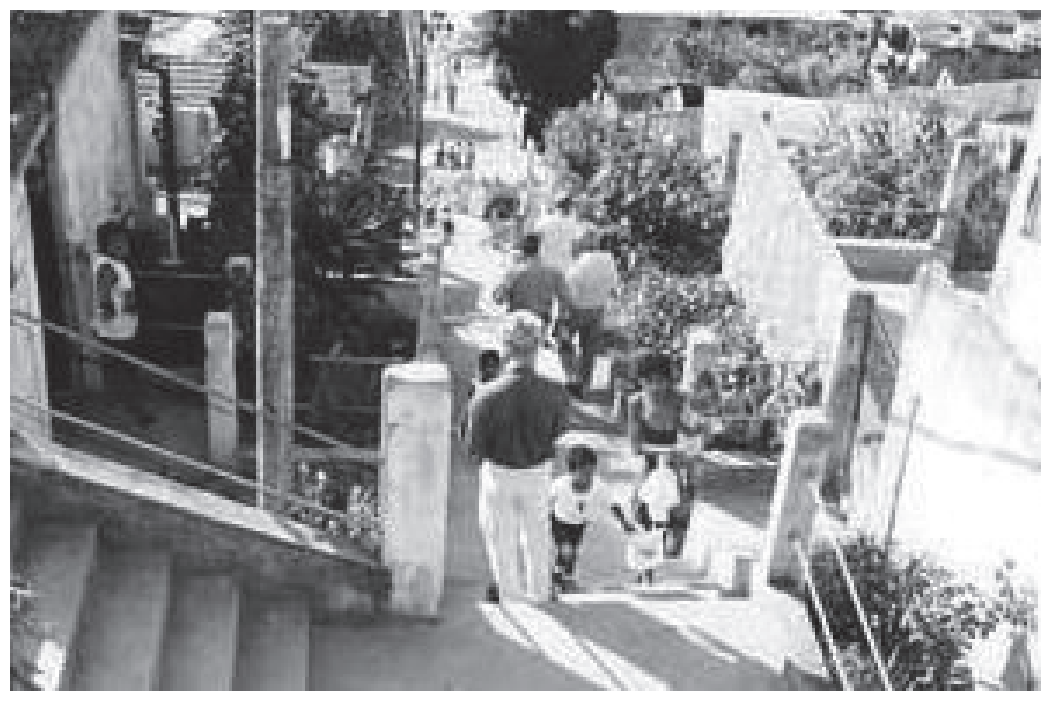

Figura 15: Rua da Balaiada . Subida do Morro da Serrinha.

Foto: http://www.vitruvius.com.br/media/images/magazines/grid 9/4fd5 O27-00-OZ.jpg

$\mathrm{Na}$ Serrinha, o destaque ficou para as casas onde viveram Silas de Oliveira, grande compositor de sambas de enredo, autor de "Aquarela Brasileira", "Os 5 bailes da história", "Heróis da Liberdade", "Senhora Tentação", entre outros; Dona Ivone Lara (Yvone Lara da Costa), destacada compositora brasileira, autora de "Sonho meu”, “Tié", "Enredo do meu Samba”; Mestre Fuleiro (Antônio dos Santos), mestre de harmonia do GRES Império Serrano, patriarca de uma família que é o esteio da escola que ajudou a fundar; Mestre Darci do Jongo (Darcy Monteiro), responsável pela difusão do Jongo e seguidor das tradiçóes herdadas de sua mãe Vovó Maria Joana (Maria Joana Monteiro), matriarca da comunidade da Serrinha, mãe de santo e jongueira; Nilton Campolino, fundador do Império Serrano, versador e compositor, que teve seus sambas "Delegado Chico Palha" e "Colete Curto, Paletó do Mesmo Pano", registrados na voz de Zeca Pagodinho; Mano Décio da Viola (Décio Antônio Carlos), grande compositor de sam- 
bas de enredo; Mestre Aniceto (Aniceto de Menezes e Silva Junior), um dos maiores versadores de partido alto de todos os tempos; Tia Doca, que foi membro da Velha Guarda da Portela e mantenedora do pagode mais antigo do Brasil e que teve suas raízes forjadas nessa comunidade; e Tio Hélio dos Santos, fundador do Império Serrano, versador e compositor, autor de um dos sambas de enredo da Escola de Samba Prazer da Serrinha, gravado pelo grupo Fundo de Quintal.

Os depoimentos também registraram a importância na memória dos moradores da sede da Escola Império do Futuro, a primeira escola mirim, de onde saíram grandes músicos, como Pretinho da Serrinha, atualmente maestro e arranjador do Seu Jorge ; a primeira sede do GRES Império Serrano, situado na casa onde viveram Tia Eulália (Eulália do Nascimento) e Seu Molequinho (Sebastiáo de Oliveira), grandes nomes da escola; e a casa onde, atualmente, vive Tia Maria do Jongo (Maria de Lourdes Mendes), responsável manutenção da herança jongueira na Serrinha.

Não posso deixar de registrar a Festa de São Jorge, padroeiro do Império Serrano, que acontece sempre no domingo posterior ao dia 23 de abril, dia do santo guerreiro. É uma procissão que sai da quadra do GRES Império Serrano, passando pela comunidade da Serrinha, retornando à quadra da escola.

No bairro de Madureira, os lugares que mereceram destaque nas entrevistas foram o Mercadáo de Madureira, grande mercado popular da região, famoso por abrigar lojas de ervas medicinais e de artigos para umbanda e candomblé e que realiza anualmente a Procissão de Iemanjá com uma carreata em direção à Praia de Copacabana; o local onde os membros do Bloco da Tamarineira se reuniam; o terreno onde é realizado semanalmente o Pagode da Tia Doca; a atual sede do GRES Império Serrano, uma das mais antigas escolas de samba do Brasil, que organiza a roda de samba Botequim do Império e a Feijoada Imperial do Império Serrano; e a atual sede do GRES Portela, a escola de Samba mais antiga do Brasil que organiza mensalmente a Feijoada da Família Portelense e anualmente a Festa de São Sebastiâo. Vale aqui contar um pouco da história dessa festa, táo conhecida pelos portelenses. Tendo como sua padroeira Nossa Senhora da Conceição, a bateria da agremiação, composta em quase sua totalidade por homens, buscou também um santo padroeiro para abençoá-la. No terreiro da mãe de santo Neném do Bambuzal, um jogo de búzios apresentou o nome de Oxossi, analogamente São Sebastião. Por isso, no dia de São Sebastiáo, a Portela realiza uma alvorada com fogos e celebra uma missa em sua quadra. Logo depois é servido um café da manhã e todos saem em procissáo até a igreja de São Sebastiâo, em Bento Ribeiro. Na volta, a procissáo faz uma parada no bar do Tuninho Macaco, figura lendária da escola, e na antiga sede, na Portelinha. O destino final é a quadra da escola onde é servida uma macarronada 
(tradição criada por Tia Vicentina), seguida uma roda de samba e de um encontro onde a bateria da Portela recebe a visita das baterias de outras escolas de samba.

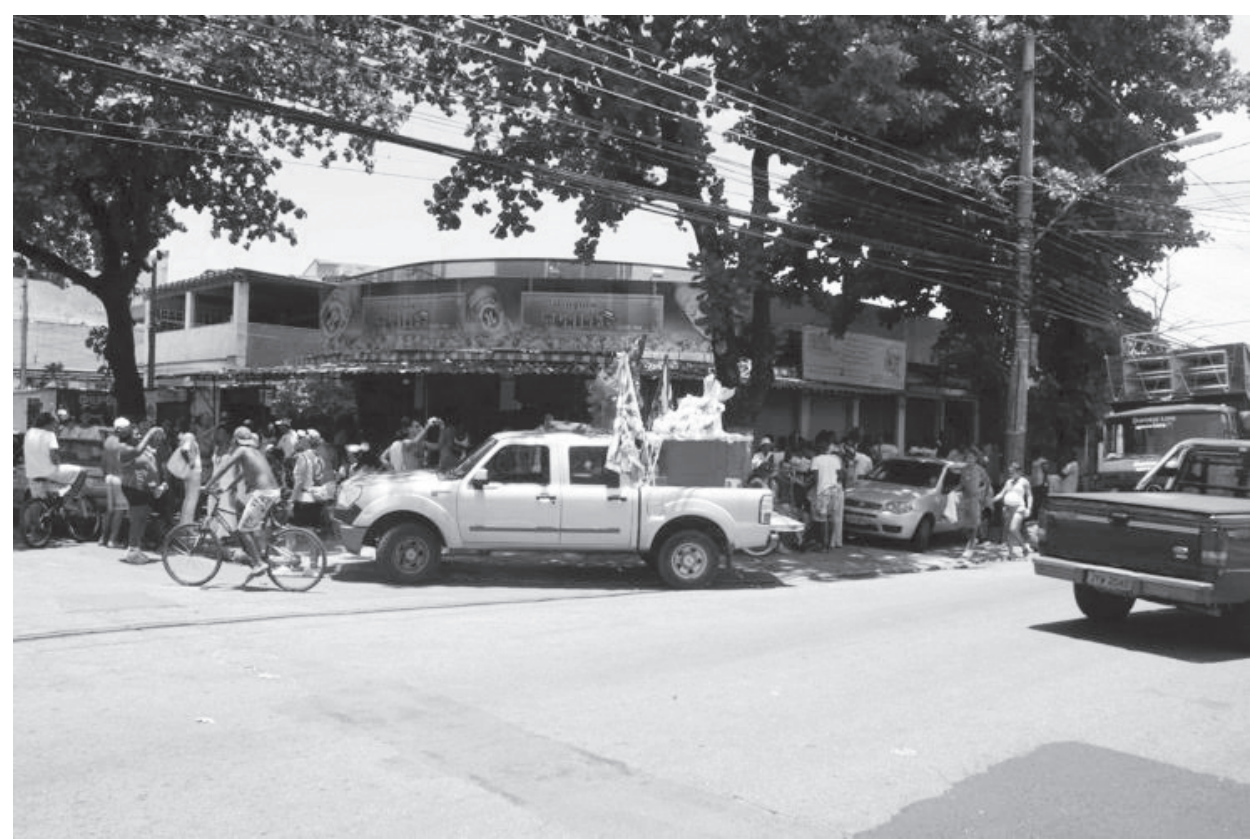

Figura 16. Procissão de São Sebastião realizada pelo GRĖ Dortela.

Fonte: Denise Barata

Mesmo sem acontecerem mais, algumas práticas simbólicas ainda se encontram vivas na memória dos moradores da região e merecem nossa atenção:

- A Festa de Nossa Senhora de Santana que acontecia na comunidade jongueira da Serrinha no dia 26 de julho. Segundo Tia Maria do Jongo, a santa era levada da Serrinha para a casa de Seu Napoleão, próximo à Praça Paulo da Portela.

- Festa de São Sebastião na Serrinha, que era organizada pela Vovó Maria Joana, matriarca e maior líder religiosa da comunidade. Anualmente, ao anoitecer, a imagem saía do alto do morro e passava pelas ruas ao redor da comunidade, que já a esperava com velas acesas, se juntando em procissão.

- O Bloco das Piranhas, que foi, por muito tempo, a referência do sábado de carnaval suburbano. Fundado por moradores do bairro, teve como uma grande referência o jogador de futebol Moisés, zagueiro ríspido, símbolo do tradicional machão. O que era interessante era a transformação desses "machões" em mulheres no carnaval, ao som de muito samba. 
- Os Blocos do Sujo da GRES Portela e do GRES do Império Serrano, que saíam durante os dias de carnaval, no horário da tarde, cantando sambas de terreiro, tais como Quantas lágrimas (Manacéia), Pecadora (Jair do Cavaquinho e Joãozinho da Pecadora) e Leviana (Zé Ketti).

\section{Entre os Objetos de Memória:}

São estes os objetos que Violette Morin chama de objetos biográficos, pois envelhecem com o possuidor e se incorporam à sua vida: o relógio da família, o álbum de fotografias, a medalha do esportista, a máscara do etnólogo, o mapa-múndi do viajante... Cada um desses objetos representa uma experiência vivida, uma aventura afetiva do morador. Diferentes são os ambientes arrumados para patentear status, como um décor de teatro: há objetos que a moda valoriza, mas não se enraízam nos interiores ou têm garantia por um ano, não envelhecem com o dono, apenas se deterioram. Só o objeto biográfico é insubstituível: as coisas que envelhecem conosco nos dão a pacífica sensação de continuidade. (BOSI, 2003, p. 26)

Vários objetos me foram apresentados após conversas informais e entrevistas. Assim, tive acesso à fotos, instrumentos musicais, cartas, cadernos com letras de musica, roupas e fantasias.

Apresento, abaixo, alguns deles:

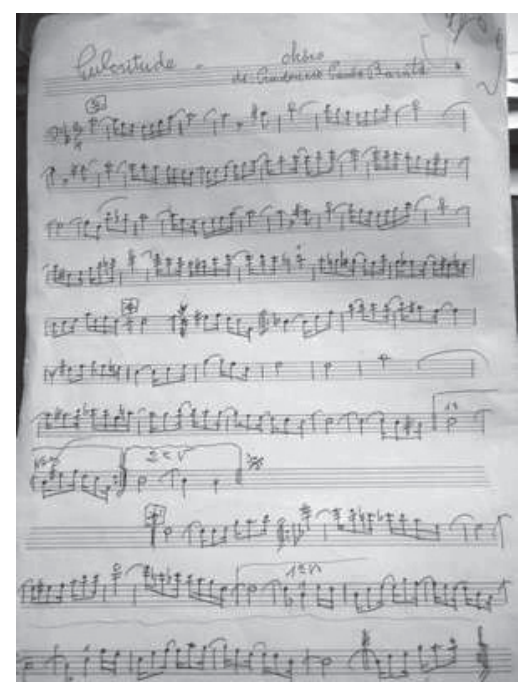

Figura 17. Partidura do chorinho "Pulcritude" de autoria de Naval, oficial da marinha, trombonista e compositor, morador do bairro de Bento Ribeiro.

Foto de Denise Barata 


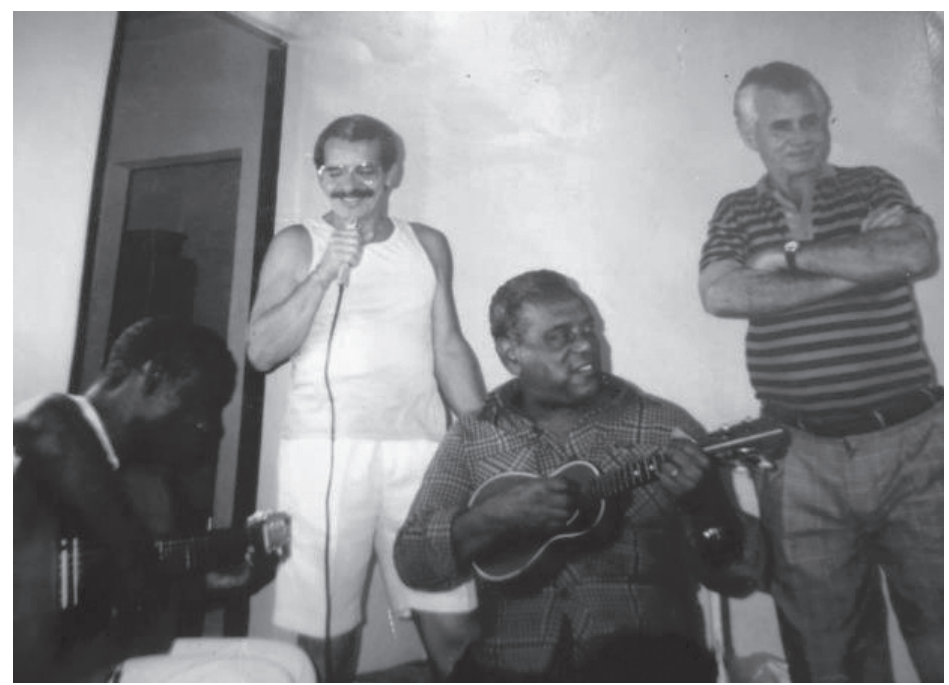

Figura 18. Seu Osmar (cavaquinista, antigo membro da Velha Guarda da Portela e morador de Marechal Hermes) e Jorge da Conceição (violonista, antigo membro da Velha Guarda da Dortela e morador de Oswaldo Cruz) acompanhados do cantor Gil Coelho e um vizinho não identificado. Fonte: Autor ainda não identificado

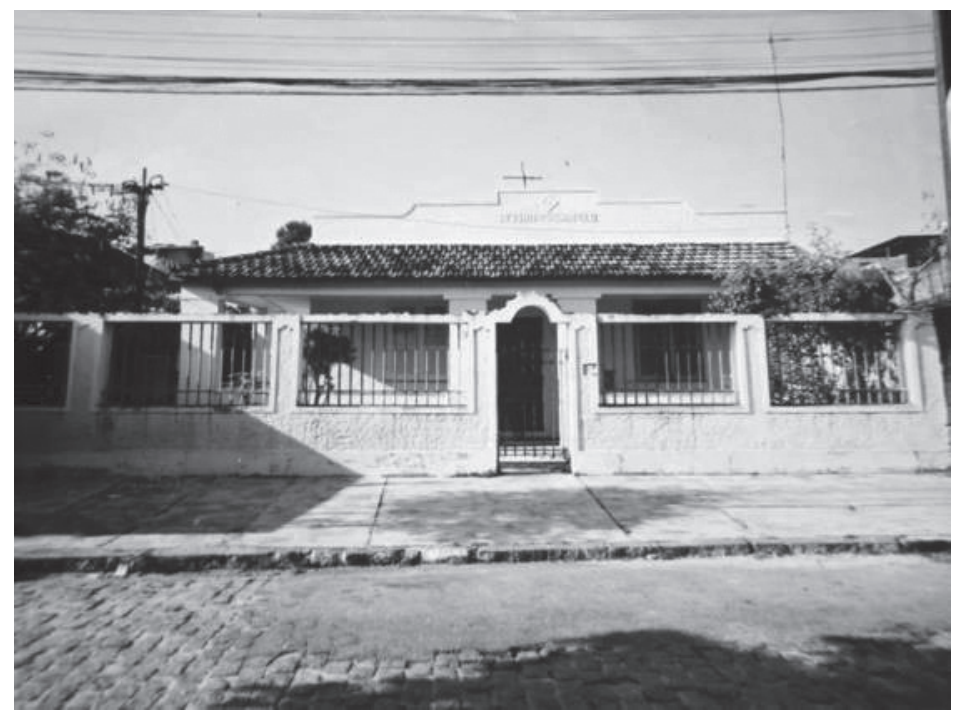

Figura 19. Casa da D. Esther, antiga festeira e líder religiosa do bairro de Oswaldo Cruz Fonte: Autor ainda não identificado 
Todo o material recebido foi copiado e seus originais devolvidos aos donos. Após a catalogação, com identificação dos autores das fotos, as datas, os nomes dos fotografados e os nomes dos doadores, diponibilizarei o arquivo.

\section{Os Cantos Negros da cidade do Rio de Janeiro}

Ao apresentar os nomes, as práticas e os lugares que foram recolhidos junto aos moradores da região, busquei demonstrar a importância desses bairros para a música brasileira. Muitos ainda insistem em buscar origens, inícios, perdendo a oportunidade de conhecer a vasta história produzida em lugares mais distantes do centro da cidade do Rio de Janeiro.

Pretendo com essa pesquisa possibilitar o levantamento e a difusão de fontes documentais bibliográficas primárias e secundárias. E aqui, quando me refiro à fonte, estou tratando de documentos visuais, sonoros, escritos (produzidos pela oralidade), além de objetos biográficos e performances. Acredito assim, que possa contribuir para reunir aqueles que se dedicam ao estudo das culturas musicais e de seus desdobramentos no movimento da diáspora, propondo uma reflexão sobre as possibilidades de manutenção e difusão de práticas e de espaços de construção de conhecimento que consideram e valorizam uma outra forma de pensar o mundo. E que, dessa forma, elas possam ser vistas com outros olhos, assim como seus produtores. Finalmente, busco construir, em conjunto com a comunidade, um trabalho que possa difundir um conhecimento que, ao ser investido de poder, contribuirá com a utopia.

\section{$\operatorname{son}$}

\section{NOTAS}

1 Cf. LIMA, Valéria Alves Esteves. A viagem pitoresca e histórica de Debret: por uma nova leitura. Tese de doutorado. Campinas: Unicamp, 2003; POTELET, Jeanine. Le Brésil vu par les voyageurs et les marins français, 1816-1840. Paris: l'Harmattan, 1993; LISBOA, Karen Macknow. A Nova Atlântida de Spix e Martius: natureza e civilização na Viagem pelo Brasil (1817-1820). São Paulo: Hucitec, 1997; MARTINS, Luciana de Lima. O Rio de Janeiro dos viajantes. O olhar britânico (1800-1850). Rio de Janeiro: Zahar, 2001; LEITE, Miriam L. Moreira. Livros de viagem: 1803-1900. Rio de Janeiro: Ed. UFRJ, 1997.

2 Obviamente, não pretendo aqui repetir os passos (bastante discutíveis) de Magalhães Corrêa, mas apenas apresentar uma ideia ainda bastante comum que desconsidera as práticas sociais e culturais distantes do centro da cidade ou as considera de forma folclórica, o que produziu inúmeras consequências aos estudos realizados sobre o samba do Rio de Janeiro. 
3 Não apresento aqui os nomes de todos os entrevistados já que, por contar com verba da Faperj, futuramente realizarei um documentário e publicarei um livro com os resultados finais desse trabalho, onde isso será feito de forma detalhada.

\section{REFERÊNCIAS}

ABREU, Regina M. R. M. O Enigma de Os Sertóes. Rio de Janeiro: Rocco/Funarte, 1998.

BARATA, Denise. Samba e Partido Alto: Curimbas do Rio de Janeiro. Rio de Janeiro: EDUERJ, 2012.

BOSI, Ecléa. O Tempo Vivo da Memória: Ensaios de Psicologia Social. São Paulo: Ateliê Editorial, 2003.

BOURDIEU, Pierre. A Ilusão Biográfica. In: AMADO, Janaína e Ferreira, Marieta (orgs.) Usos e Abusos da História Oral. Rio de Janeiro: Fundação Getúlio Vargas. 1996.

CORRÊA, Armando Magalhães. O Sertão Carioca. Rio de Janeiro: Imprensa Nacional, 1936.

DE VARINE, Hugues. As Raízes do Futuro: O Patrimônio a Serviço do Desenvolvimento Local. Porto Alegre: Medianiz, 2012.

DELEUZE, Gilles \& GUATTARI, Félix. Mil Platôs. Volume 1. Rio de Janeiro, Editora 34: 1995.

FERREIRA, Jerusa Pires. As Armadilhas da Memória e Outros Ensaios. Cotia: Ateliê Editorial, 2003.

KIRST, Patrícia Gomes \& Fonseca, Tania Mara Galli (orgs.). Cartografias e Devires - a Construção do Presente. Porto Alegre: Editora UFRGS, 2003.

FRANCO, José Luiz de Andrade \& DRUMMOND, José Augusto. Armando Magalhães Corrêa: Gente e Natureza de um Sertão quase Metropolitano. In: História, Ciências e Saúde - Manguinhos. Rio de Janeiro. Vol.12, no.3, Sept./Dec. 2005. Disponível em http://www.scielo.br/scielo.php?script=sci_arttext\&pid=S0104-59702005000300021\&lng=p t\&nrm=iso\&tlng=pt. Acesso em: 28 jun $201 \overline{5}$.

FREITAS, Pablo. O Interior do Rio de Janeiro e o Sertão Carioca. In: Revista Perspectiva Sociológica. Rio de Janeiro. $\mathrm{n}^{\circ} 6$ e 7, Jan./Jul., 2011. Disponível em: http://www.cp2.g12.br/blog/ perspectivasociologica/edicoes-anteriores/jan-jul-2011-no-6-e-7/o-interior-do-rio-de-janeiro-e-o-sertao-carioca/. Acesso em: 17 mar 2015.

GALEANO, Eduardo. O Livro dos Abraços. Porto Alegre: L\&PM, 2002.

HOCHMAN, Gilberto. Logo Ali, no Final da Avenida: Os Sertões Redefinidos pelo Movimento Sanitarista da Primeira República. História, Ciências e Saúde -Manguinhos. Rio de Janeiro. Vol.5, Jul 1998. Disponível em http:/www.scielo.br/scielo.php?pid=S0104=59701998000400012-\&scriptsci_arttextAcesso em: 10 jun 2015

LE GOFFF, Jacques. História e Memória. Campinas, São Paulo: Editora da UNICAMP, 1994.

MORAES, Antônio Carlos Robert. O sertão: um “outro" geográfico. Revista Terra Brasilis, Rio de Janeiro, v. 4/5, 2003, p.11-23.

NORA, Pierre. Entre Memória e História: a problemática dos lugares. In: Projeto História. São Paulo: PUC, n. 10, pp. 07-28, dezembro de 1993.

OLIVEIRA, Ricardo de. Euclides da Cunha, Os sertões e a invenção de um Brasil profundo. In: Revista Brasileira de História. São Paulo. Vol. 22, no.44, 2002. Disponível em http://www.scielo.br/scielo.php?pid=S0102-01882002000200012\&script=sci_arttext. Acesso em: 21 jul 2015.

PÁDUA, José Augusto. Um Sopro de Destruição: Pensamento Político e Crítica Ambiental no Brasil Escravista (1786-1888). Rio de Janeiro: Jorge Zahar, 2002. 
SARMENTO, Carlos Eduardo. Pelas Veredas da Capital. Magalhães Corrêa e a Invenção Formal do Sertão Carioca. Rio de Janeiro: CPDOC, 1998. Disponível em http://cpdoc.fgv.br/producao intelectual/arq/1094.pdf. Acesso em: 28 jun 2015.

SLENES, Robert. Malungu, Ngoma Vem! África Coberta e Descoberta no Brasil. Revista USP. $\mathrm{n}^{\circ}$ 12, dez/fev 1991-1992. p 1-20.

SODRÉ, M. A Verdade Seduzida: Por um Conceito de Cultura no Brasil. Rio de Janeiro: Codecri, 1977.

SODRÉ, M. Samba, o Dono do Corpo. Rio de Janeiro: Mauad, 1988.

SOUZA, Candice Vidal e. O Sertão Amansado. In: Revista Sociedade e Cultura. Goiânia. Vol. 13, n. 1, enero-junio, 2010, pp. 101-110. Disponível em: http://www.redalyc.org/pdf/703/70315011010. pdf. Acesso em: 21 jul 2015.

ZUMTHOR, Paul. A Letra e a Voz. São Paulo: Cia das Letras, 1993.

ZUMTHOR, Paul. Introdução à poesia oral. São Paulo: HUCITEC, 1996.

ZUMTHOR, Paul. Tradição e esquecimento. Sáo Paulo: HUCITEC, 1997.

\section{Resumo}

A partir da ideia de sertão desenvolvida por Magalhães Correa, apresento a pesquisa que venho realizando sobre a memória musical na região da Grande Madureira, ainda desconhecida para muitos moradores da "costa" da cidade. Aqui relaciono música e território, especialmente Chorinho com Marechal Hermes; Samba de Gafieira com Bento Ribeiro; Samba de Terreiro e Jongo com Oswaldo Cruz e Serrinha. Os lugares de memória da regiáo já foram mapeados, com destaque para a casa dos músicos ilustres e para os espaços de produção de música; e as imagens e as entrevistas estáo sendo organizadas. Com esta pesquisa, pretendo mover a centralidade da história do samba do centro da cidade para esta regiáo da periferia.

\section{Abstract}

From the idea of sertão developed by Magalhães Correa, I present the research who I am accomplishing about the musical memory in the Great Madureira, and that is still unknown to the residents of the "coast" of the city. Here I relate the music with the territory, especially Chorinho with Marechal Hermes; Samba de Gafieira with Bento Ribeiro; Samba de Terreiro and Jongo with Oswaldo Cruz and Serrinha. The places of memory already were mapped, with highlight for distinguished musicians' home and for the music production spaces; and the pictures and the interviews are been organized. With this research, I aim to move the centrality of history of the samba from the center of the city to this region of the outskirts.

Légua \& Meia Revista de Literatura e Diversidade Cultural
BARATA, Denise. No sertão da minha terra - Memórias e musicalidade nos subúrbios do Rio de Janeiro. Légua \& Meia: Revista de literatura e diversidade cultural. Feira de Santana: UEFS, A. $14, \mathrm{n}^{\mathrm{o}}$ 7, 2016, p 188-214. 